\title{
Literatura e civilização em Portugal de Álvares de Azevedo, editado por Roberto Acízelo de Souza
}

Everton Barbosa Correia Professor de Literatura Brasileira da Universidade do Estado do Rio de Janeiro. Doutor em Letras pela Universidade de São Paulo. Email: evertonbcorreia@gmail.com

\section{Resenha de:}

AZEVEDO, Álvares. Literatura e civilização em Portugal. Roberto Acízelo de Souza (Ed.). Rio de Janeiro: Caetés, 2016.

Com a premência da produção literária contemporânea, cumpre que se pergunte qual o sentido de ainda se publicar algo do Oitocentos brasileiro, tratando-se de obra já editada e pouco lida. Este é o caso da nova edição de Literatura e civilização em Portugal de Álvares de Azevedo, com organização de Roberto Acízelo de Souza, pela Editora Caetés, que veio a lume em fins de 2016 e agora entra em circulação. A editora pode ser identificada pela própria produção do organizador, cujo trabalho de divulgação de obras importantes para a constituição da tradição literária brasileira - a exemplo de Historiografia da literatura brasileira: textos fundadores (1825-1888) e Curso de literatura portuguesa e brasileira (Francisco Sotero dos Reis), para ficar no ano de 2014 - já lhe rendeu notório reconhecimento, tendo recebido os prêmios Jabuti e da Academia Brasileira de Letras (ABL) em 2015, pela contribuição para a crítica literária e também recebeu o prêmio da Associação Brasileira de Editoras Universitárias (ABEU) na categoria Humanidades, pelo título Do mito das musas à razão das letras: textos seminais para os estudos literários (século V a.C. - Século XVIII), pela editora Argos. Feitas as apresentações editoriais e do organizador, todavia perdura a pergunta: qual o significado da publicação isolada da obra édita de Álvares de Azevedo, Literatura e civilização em Portugal, que nunca atingiu o público em vida escolar nem vai atingir? 
O truísmo de que precisamos cuidar dos nossos mortos parece não responder satisfatoriamente ao dilema, uma vez que o nosso presente pede reza de modo muito mais impositivo, quase asfixiante até. Não é, pois, como oposição ao presente que a leitura do poeta paulista se coloca, e sim como contraponto a um possível entendimento do próprio passado, ao qual a nova edição parece pedir licença para redimir equívocos sucessivos em torno do autor, do movimento literário a que foi atrelado, e da própria compreensão alvaresazevediana de cultura e de história, o que não deve ser pouco para um poeta só.

A publicação propriamente se constitui de duas esferas de intervenção no texto original, através dos textos introdutórios ("Apresentação" e "Critérios de edição") e das notas. É como se o organizador se dirigisse aos leitores, alertando para duas extensões de leitura: uma de maior alcance, ilustrada pela compreensão do autor e pelo entendimento possível de tal compreensão - ilustrada pelos textos introdutórios; outra de menor alcance - ilustrada pelas notas - que esclarece o sentido das referências utilizadas e materializa no espaço da página uma compreensão histórica que é do autor e que o organizador atualiza. A depender da opção do leitor por uma ou outra extensão de leitura, o texto sai mais legível, porque é inapelavelmente como cifra que ele se apresenta e agora parece remediado: o poeta se apresenta como um pensador precário da sua cultura. A precariedade de seu pensamento está condicionada por um fato incontornável: era jovem e morreu jovem. Para não estender a controvérsia, foi a mesma limitação etária que levou Mário de Andrade (2002) a depurar sua hipotética mentalidade juvenil no artigo "Amor e medo", coligido em Aspectos da literatura brasileira e publicado inicialmente em 1943, cujo desdobramento crítico foi levado a instâncias masturbatórias no artigo "Cavalgada ambígua", constante na reunião de ensaios feita por Antonio Candido (2000) sob o título de Na sala de aula. Tais referências se justificam porque impõem que se fale da influência da visão de Mário de Andrade sobre o poeta romântico que atinge todos os leitores seguintes, incluindo aí até mesmo Antonio Candido. Ao que parece, a partir de agora, tal influência passa a ganhar outros contornos: a limitação etária radicada na precariedade do pensamento do autor fica explicitada no excesso de citações ou na superficialidade da abordagem histórica, que tem o seu poder de revelação sobre o 
entendimento de nossa cultura, onde a literatura pode ocasionalmente se estacionar. Não é mais porque o ambiente tacanho do século XIX brasileiro não permitisse aquilo que só veio a se consumar no século seguinte como uma boa nova, e sim porque qualquer que seja a herança do Oitocentos brasileiro, ela não pode ser desvinculada dos séculos antecedentes, inclusive a de uma idade média que não tivemos e que só pode ser saldada pela pátria portuguesa.

O espectro que se afigura não é o que um rapaz de vinte anos pode prefigurar do futuro que não viu, e sim do passado que ecoa nos seus ouvidos e nos seus atos como partes dispersas de uma cultura em processo, o que vem a ser mais consequente enquanto estratégia de leitura, ao menos sob o ponto de vista histórico. Seria muito fascinante que o medievo português não repercutisse entre nós, porque seríamos o futuro que poderia ter sido e que não foi. Tal como foi, o que dispomos aí está pelo modo como deve ter sido, já que a história só pode se ocupar dos artefatos que se oferecem como projeção de uma mentalidade já existente e não da vindoura ou da que desejarmos retrospectivamente. Portanto, é como angulação do quadrante lusitano que a nova leitura de Álvares de Azevedo se insinua, e não é porque ele não tivesse vínculos com o chão brasileiro, o que tinha a contento e até sobejamente, mas sim para o exercício de humildade de dar ao luso o que é do luso, como se vê, no subtítulo "Hispânia" do capítulo "Portugal".

"Daí vê-se: os vezos e usanças das colônias do Brasil eram os mesmos dos portugueses: a língua sempre foi a mesma. Os poetas, cuja nascença tanto honra o Brasil, alçaram seus vôos de águia na mãe pátria. Com pouca exceção, todos os nossos patrícios que se haviam erguido poetas tinham-se ido inspirar em terra portuguesa, na leitura dos velhos livros e nas grandezas da mãe pátria. José Basílio e Durão não foram tão brasileiros como se pensa. Os heróis do Uruguai e do Caramuru eram portugueses. Não há nada nesses homens que ressumbre brasileirismo; nem sequer o brado de homem livre da colônia - nada -, até o canto entusiasta da mocidade ardente de Antônio Pereira Sousa Caldas, até as gritas livres da insurreição de Tiradentes, esse prelúdio sublime de uma orquestra de clamores de guerra ao brilhar das palmas da independência, procelária que aí vinha desgarrada ante o bafo da tormenta. E, contudo, o representante dessa época, Gonzaga, apesar de todos os louvores do Parnaso e do Plutarco do Dr. Pereira da Silva, não está muito claramente provado 
que fosse brasileiro. Eis, portanto: os usos eram os mesmos. Os homens de aquém-mar sentiam como os colonizadores." (AZEVEDO, 2016, p. 63-64)

O trecho destacado impressiona pelo seu poder de síntese, diante de uma questão espinhosa, quando estava em voga com todo o fervor a afirmação nacional. Cumpre referir que o trecho citado é acompanhado por meia dúzia de notas de rodapé, que explicam os nomes mais do que a mentalidade da época ou a expressão individual do autor, que ficam para ser decifradas pelo leitor. Por uma razão ou por outra, configura-se a perspectiva historiográfica de leitura, para a qual as referências valem mais do que o conjunto de ideias que, eventualmente, viessem identificar um tempo ou uma autoria. Se Álvares de Azevedo se empenha em ser consequente na sua descrição do percurso poético brasileiro, caudatário do português, não será menor o empenho do organizador em dar a ver o conjunto de referências que animam o escrito. $\mathrm{O}$ que se coloca como estratégia de leitura em que serpenteia um método historiográfico é a premissa de que o registro gráfico deve se submeter aos limites da expressão do seu tempo, antes de suportar as projeções de tempos outros. É claro que nosso olhar carrega vícios que se denunciam quando olhamos para o passado com superioridade, porque, afinal de contas, dispomos de celulares e descobrimos como usar o ar-condicionado. O que não fica nítido de um relance só é a certeza de que a inscrição de um novo tempo suprima por completo as eras antecedentes, que inda estão redivivas em nós, senão como uma fatalidade histórica, decerto como um sintoma do que insistimos em negar e que se revela mais incisiva e insidiosamente do que imaginamos ou quiséramos. Como contraponto ao raciocínio, a nova edição da obra de Álvares de Azevedo se faz uma mostra singela, modesta e certeira, porquanto obriga o leitor interessado em decifrar a quimera chamada Brasil a fazer uma parada.

\section{REFERÊNCIAS}

ANDRADE, Mário. Amor e medo. Aspectos da literatura brasileira. 6. ed. Belo Horizonte: Itatiaia, 2002. p. 197-230.

AZEVEDO, Álvares. Literatura e civilização em Portugal. Edição de Roberto Acízelo de Souza. Rio de Janeiro: Caetés, 2016. 
CANDIDO, Antonio. Cavalgada ambígua. Na sala de aula. 8. ed. São Paulo: Ática, 2000. p. 38-53

REIS, Francisco Sotero dos. Curso de literatura portuguesa e brasileira. Organização de Roberto Acízelo de Souza. Rio de Janeiro: Caetés, 2014.

SOUZA, Roberto Acízelo (Org.). Historiografia da literatura brasileira: textos fundadores (1825-1888). Rio de Janeiro: Caetés, 2014.

Do mito das musas à razão das letras: textos seminais para os estudos literários (século V a.C - século XVIII). Chapecó: Argos, 2014. 